\title{
Climate impacts on feeding and condition of capelin Mallotus villosus in the Barents Sea: evidence and mechanisms from a 30 year data set
}

\author{
Emma L. Orlova ${ }^{1, *}$, Galina B. Rudneva ${ }^{1}$, Paul E. Renaud ${ }^{2}$, Ketil Eiane $^{3}$, \\ Vladimir Savinov ${ }^{2}$, Alexandr S. Yurko ${ }^{1}$ \\ ${ }^{1}$ Polar Research Institute of Marine Fisheries and Oceanography (PINRO), 6 Knipovich St., 183763 Murmansk, Russia \\ ${ }^{2}$ Akvaplan-niva, Polar Environmental Centre, 9296 Tromsø, Norway \\ ${ }^{3}$ Faculty of Bioscience and Aquaculture, Bodø University College, 8049 Bodø, Norway
}

\begin{abstract}
Capelin Mallotus villosus is one of the most abundant fish species in the Barents Sea and is a critical link between zooplankton and commercial species such as Atlantic cod. Climatic conditions influence the population structure, feeding, and biological condition of capelin by affecting their distribution and that of their zooplankton prey. We sampled more than 1500 stomachs of capelin from 1978, 2002, 2003, 2006, and 2007 spanning years with cold, moderate, and warm climatic conditions, and examined the distribution of their major prey items: euphausiids and Calanus copepods. Capelin distribution is broader during warmer years, especially in the north and northeast. Copepods and euphausiids dominated the diets of capelin, but hyperiid amphipods and chaetognaths were also important. Diet and stomach fullness showed significant geographic variability within the Barents Sea, and varied among years depending on whether the climatic conditions were warmer or colder than the long-term average. Abundance of inter- and intraspecific competitors appears to affect diet, feeding intensity, and fat content. Fat content is an important indicator of capelin reproductive potential and their food value for predators, and was highest in northeastern regions and strongly influenced by capelin diet. Analyses of these 5 years of data plus 10 more years from previously published studies indicate the importance of climate drivers for determining fat content. Mechanisms are complex, however, and many factors directly and indirectly influence condition of this critical species in the Barents Sea ecosystem.
\end{abstract}

KEY WORDS: Calanus - Dietary composition · Euphausiid · Fat content $\cdot$ Interannual variability

\section{INTRODUCTION}

The efficient transfer of energy from primary producers to higher trophic levels is responsible for the rich communities of seabirds and marine mammals supported by Arctic marine food webs. Lipids are concentrated in many animals, as these organic compounds provide dense energy reserves that sustain organisms during periods of low primary production, as well as fueling short- and long-distance migrations, and supporting reproduction in resident vertebrate and invertebrate fauna. Zooplankton, copepods and euphausiids in particular, play critical roles in this energy flux within the pelagic zone (Falk-Petersen et al. 1990, 2000) by grazing on phytoplankton during seasonal blooms and, in turn, being consumed by planktivorous fish such as capelin and herring. Optimal fat accumulation in these fish relies on abundant late-stage Calanus spp. copepods throughout the summer, and euphausiids in late summer and early autumn (e.g. Orlova et al. 2002b). The distribution and abundance of their zooplankton prey, however, can be strongly impacted by climatic variability (e.g. Orlova et al. 2002a, Ellingsen et al. 2008) and human activities in an increasingly ice-free Arctic, with important implications for the condition of planktivorous fish and energy transfer to higher trophic levels (Orlova et al. 2005). 
Capelin Mallotus villosus plays a key role in the pelagic ecosystem of the Barents Sea and throughout the Arctic. It is an important grazer of zooplankton, and can strongly affect their populations (Hassel et al. 1991, Gjøsæter et al. 2002, Stige et al. 2009). In general, prey selection by capelin is strongly related to fish size (Gjøsæter et al. 2002, Orlova et al. 2002a, 2009a), but the abundance and composition of the zooplankton community varies considerably in time and space. Climate variability can affect this relationship by altering the phenology of zooplankton development (Orlova et al. 2002b), advection of zooplankton into and within the Barents Sea, migration routes of capelin associated with ice-edge retreat, and abundance of potential competitors (e.g. Orlova et al. 2009a).

Capelin is also the most important prey item for Atlantic cod in the region (Bogstad \& Gjøsæter 2001, Dolgov 2002), and a main food source for piscivorous seabirds and marine mammals (Gjøsæter 1998, Folkow et al. 2000, Nilssen et al. 2000). Capelin populations have experienced dramatic fluctuations in abundance and structure in the Barents Sea (Ushakov \& Ozhigin 1987, Ushakov 2000), and this has been tied to climatic conditions (Gjøsæter and Loeng 1987, Orlova et al. 2002a), predation (Gjøsæter \& Bogstad 1998, Hjermann et al. 2004b, 2007), and fishing pressure (Hjermann et al. 2004a, Wassmann et al. 2006 and references therein). Because of the central role of capelin in the ecosystem, it is critical to understand how interannual variability in environmental and biological parameters alters conditions for capelin feeding, growth, and fat accumulation.

Climate variability is of particular importance in the Barents Sea because it affects the volume and heat content of Atlantic water entering the region. Oceanographic data from the Kola Transect in the south-central Barents Sea (along the $33^{\circ} 30^{\prime}$ E meridian) provides evidence that warmer and colder years and/or periods in the Arctic region are linked with both larger-scale climatic indices (North Atlantic Oscillation) and regional ecology (Ottersen \& Stenseth 2001). Furthermore, Ellingsen et al. (2008) used an ecosystem model driven by recent climate projections to predict that temperature of Atlantic water entering the Barents Sea over the next $50 \mathrm{yr}$ will increase and lead to altered phytoplankton and zooplankton production. It is important, therefore, to understand how variation in heat content of the Barents Sea influences ecosystem functioning, to better predict impacts of projected climate warming.

In the present study we examined the distribution, feeding, and fat content of capelin in cold, moderate, and very warm years sampled during the last $30 \mathrm{yr}$. Specifically, we asked: (1) How does climate variability affect feeding of capelin on zooplankton prey? (2) How is this reflected in lipid content and, thus, the ability to transfer energy to higher trophic levels? (3) What are the general mechanisms by which climatic conditions may affect these processes?

\section{MATERIALS AND METHODS}

Thermal conditions of a particular year were assigned based on average monthly anomalies of the water temperature in the 0-200 m layer from Stns 3 to 7 along the Kola Meridian section $\left(33.5^{\circ} \mathrm{N}\right.$ from the Russian coast to approximately $75^{\circ} \mathrm{N}$; Boitsov 2008). Based on these data, 1978 was determined to be a very cold year (anomalies $\geq 0.75^{\circ} \mathrm{C}$ below normal), 2002 and 2003 were moderately warm years (from $0.25^{\circ} \mathrm{C}$ below normal to $0.75^{\circ} \mathrm{C}$ above normal), and 2006 and 2007 were categorized as very warm (anomalies $\geq 0.75^{\circ} \mathrm{C}$ above normal; see Table 1). Oceanographic data from the Kola Transect have been collected for more than 100 years and reflect the relative amount of heat from Atlantic water entering the Barents Sea. These data also correlated well with the anomaly of the ice-free area in the Barents Sea for May-June (Orlova et al. in press).

Distribution of capelin and potential prey items was determined during regular survey cruises conducted in different fishing areas of the northern Barents Sea (Fig. 1). Capelin distributions were based on abundance data from survey catches, fishing statistics, and trawl and acoustic surveys (Anonymous 2008). Since 2000, these techniques have been standardized as part of the Polar Research Institute of Marine Fisheries and Oceanography (PINRO)-Institute of Marine Research Joint Monitoring Program. Capelin data from 1978 were collected by different methods and only general patterns are described (see Orlova et al. in press for more information). All zooplankton in the present study was collected in a depth-stratified manner with a Juday net (37 mm opening diameter, $180 \mu \mathrm{m}$ mesh). Considerable variation has been observed in the distribution and abundance of copepod life stages during the study period. It is beyond the scope of the present study to go into detail on this here, but specific references will be made in relevant sections of the 'Discussion'. It is covered in detail in Orlova et al. (2002a, in press).

Capelin feeding intensity was estimated using a mean stomach fullness index (SFI), indicated by the ratio of the total mass of prey in the gut to the total mass of the individual capelin, and expressed in prodecimille (parts per $10000, \%$ o) format. To characterize the diet composition of capelin, approximately 25 stomachs from capelin from each size class from each sample were collected, fixed in $4 \%$ formalin, and analysed by identifying contents to lowest practical 


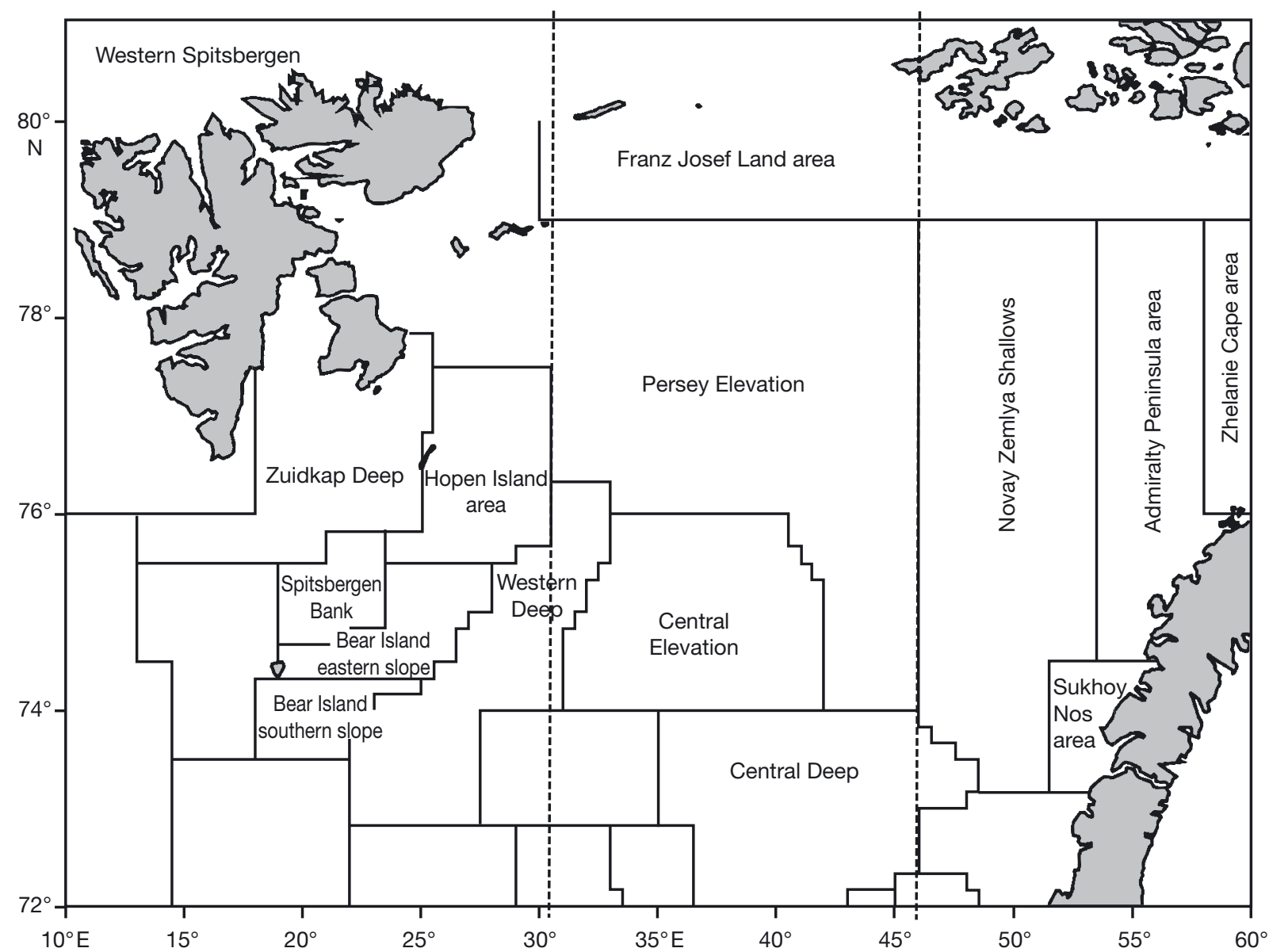

Fig. 1. Sampling areas for capelin and zooplankton in the northern Barents Sea. Dashed lines indicate approximate division into northeastern, central, and northwestern regions

taxonomic unit. Prey mass (wet weight, WW) was estimated for each taxonomic group and taxon-specific contribution to total diet mass was estimated for each $2 \mathrm{~cm}$ size class (9 to $19 \mathrm{~cm}$ standard length) of capelin. This was performed for 1978, 2002, 2003, 2006, and 2007, amounting to a total of 1590 stomachs analysed. It is not known how long stomach contents last before they can no longer be identified. In all of our studies, zooplankton from most stomach contents was identified to stage, and little remained unidentified. In general, capelin feed most heavily from early morning to late afternoon (E. Orlova pers. obs.), although this can vary with location and time of year (e.g. Gjøsæeter 1998), and perhaps with vertical migratory behavior in both capelin and their prey. This information comes from variability in gut fullness over the day, so some of the stomach contents are clearly digested. Gut contents in the present study were collected at multiple times of day and during many years of field surveys. Thus we believe our results to be unbiased in this manner.

Body condition of capelin was assessed at every sampling station by estimating the fat content in muscle tissue (\%) from approximately 25 individual fish from a variety of size classes using the method of Lazarevsky (1955). This standard method entails Soxhlet extraction of dried capelin tissue with diethyl ether for $48 \mathrm{~h}$.

Fat content of capelin varies seasonally; thus, for purposes of comparison, we have limited our analyses to data from the end of the main feeding period in the Barents region (September). Stations were binned into 3 regions in the northern Barents Sea (Fig. 1): northwestern, combining fishing areas around Hopen and Bear Islands, and around Spitzbergen $\left(10\right.$ to $\left.30^{\circ} \mathrm{E}\right)$; central, combining Central Deep, Central Elevation, Persey Elevation, and Franz Josef Land (30 to $45^{\circ} \mathrm{E}$ ); and northeastern, Novaya Zemlya Shallows and Admiralty Peninsula ( 45 to $60^{\circ} \mathrm{E}$ ). Fat content data from individual fish from 1978 were not available; therefore, our analysis for this year is limited to general patterns and ranges, and statistical analyses were run only on data from 2002 to 2007. A 3-way ANOVA was performed on data from 2002, 2006, and 2007 for the 2 most abundant size classes (13.1-15.0 and 15.1-17.0 cm). Significant effects were further tested using a Neumann-Keuls 
multiple comparisons test $(\alpha=0.05)$. Significant results from the 3 -way ANOVA were explored more deeply using a 1-way ANOVA investigating the effect of year (2002, 2003, 2006, 2007) on fat content of all 13.1 to $19.0 \mathrm{~cm}$ fish from the Central region. A second 1-way ANOVA tested for differences among regions for 13.1 to $19.0 \mathrm{~cm}$ fish collected in 2006. Neumann-Keuls tests followed to investigate significant differences. Performing these two 1-way ANOVAs does constitute some multiple testing of data, but also allows inclusion of more fish size classes $(17.1-19.0 \mathrm{~cm})$ and a better investigation of year (first ANOVA adds 2003 data) and region (second ANOVA investigates all 3 regions).

Finally, we use climatological data and stock assessments from 15 years between 1978 and 2007 for Barents Sea capelin in a multiple linear regression to investigate potential drivers of capelin fat content. Thermal anomalies at the Kola Transect (Boitsov 2008), the winter (December-March) principal component-based North Atlantic Oscillation (NAO) index (Hurrell 1995, and updates from www.cdg.ucar. edu/cas/jhurrell/indices.html), and capelin biomass (Orlova et al. in press) were used as independent variables; the maximum fat content for each year was the dependent variable (Table 1).

\section{RESULTS}

\section{Distribution and abundance of capelin and their prey}

Thermal conditions in the Barents Sea have a significant impact on capelin distribution. In the moderately warm years $(2002,2003)$, main areas of distribution were further south than in the very warm years $(2006,2007)$. In 2003, capelin distribution did not reach above $78^{\circ} \mathrm{N}$ and peak concentrations were recorded below $76^{\circ} \mathrm{N}$ in the western Barents Sea (Anonymous 2003), but were relatively modest, i.e. not above $10 \mathrm{t}$ (n mile) ${ }^{-2}$; (Fig. 2). The moderately warm 2002 had more extensive feeding distributions, located farther north and west than in the somewhat cooler 2003 (Anonymous 2002). Additionally, very high concentrations, up to $100 \mathrm{t}$ (n mile) ${ }^{-2}$ were found over the Persey Elevation (Fig. 2). The very warm years witnessed expanded ranges of capelin to areas north of Svalbard (above $80^{\circ} \mathrm{N}$ ), and along the west coast of Spitzbergen. Main concentrations were again located over the Persey Elevation with up to $50 \mathrm{t}$ (n mile) ${ }^{-2}$, with a secondary concentration over the Central Elevation in 2007 (Fig. 2). In 1978, capelin were widespread in the western and southern areas of the study region, but reduced in the north and east (Orlova et al. in press): the main concentrations were located south of $77^{\circ} \mathrm{N}$ and fish were rarely found east of $41^{\circ} \mathrm{E}$ (nearly absent from eastern Persey Elevation and Novaya Zemlya Shallows; Dommasnes et al. 1979).

Euphausiid distribution was observed to vary considerably between the very cold (1978) versus very warm (2007) years. In 1978, euphausiids were concentrated in the western areas (Spitzbergen Bank, Bear Island, and Hopen Island area), and along the Norwegian/ Russian coast, and the population was nearly exclusively composed of the Atlantic species Thysanoessa inermis (Fig. 3A,B). In contrast, the very warm 2007 was characterized by widespread distributions of euphausiids, covering nearly all of the western and central Barents Sea up to $78^{\circ} \mathrm{N}$ (Fig. 3C,D). Again, T. inermis comprised the bulk of the euphausiid population, although T. longicaudata was important in the areas south of Bear Island. Densities in 2007 were relatively uniform and $>500$ ind. $1000 \mathrm{~m}^{-3}$, whereas concentrations $>200$ ind. $1000 \mathrm{~m}^{-3}$ were largely restricted to the bank margins in 1978 (Fig. 3).

\section{Spatial variability in capelin diets and feeding intensity}

During the very cold 1978, capelin fed primarily on copepods in the western areas south of $77^{\circ} \mathrm{N}$ during summer, but shifted to euphausiids in more central 

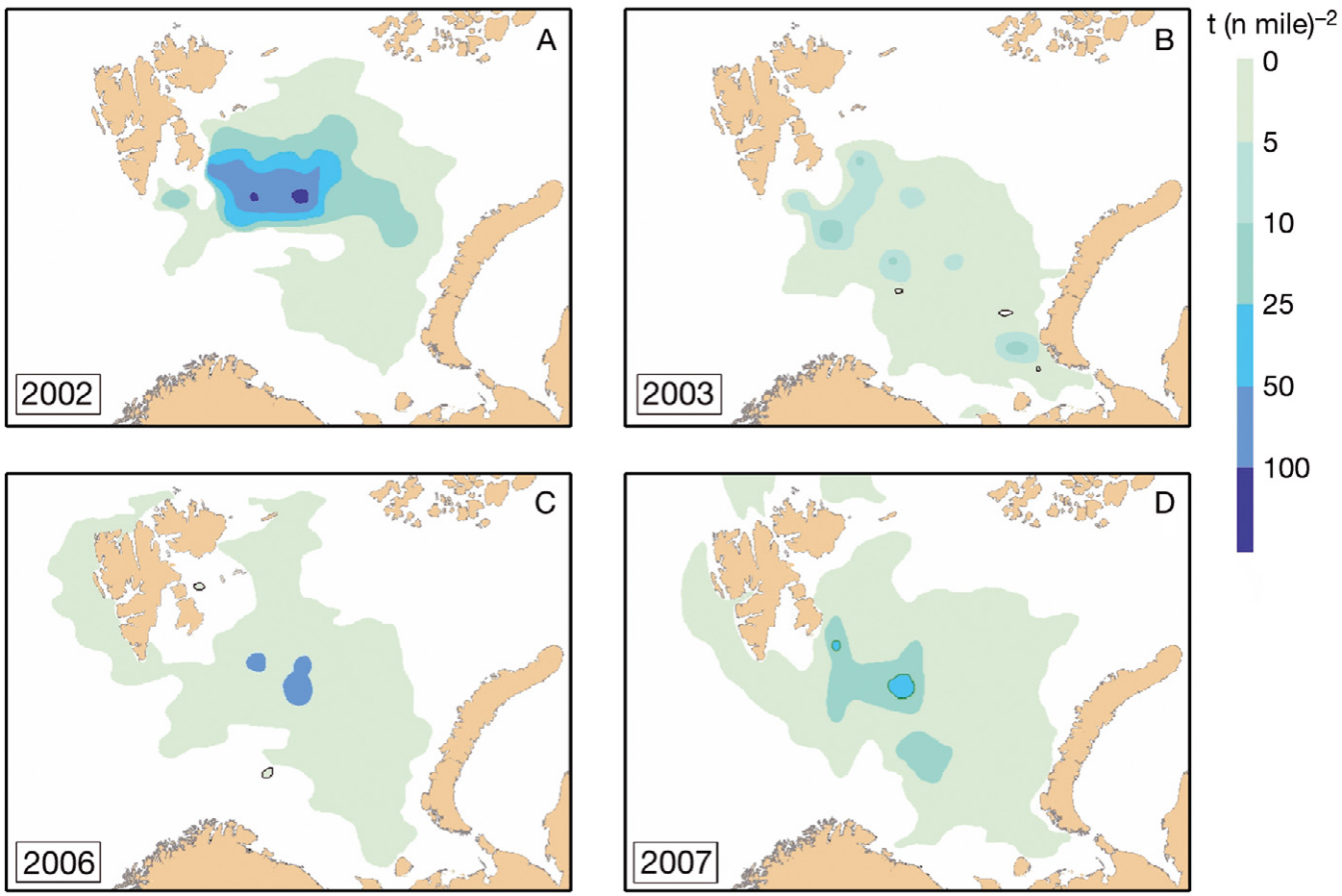

100

Fig. 2. Mallotus villosus. Capelin distributions in $\mathrm{t}(\mathrm{n} \text { mile })^{-2}$ in September-October of moderately warm years (A) 2002 and (B) 2003, and very warm years (c) 2006 and (d) 2007
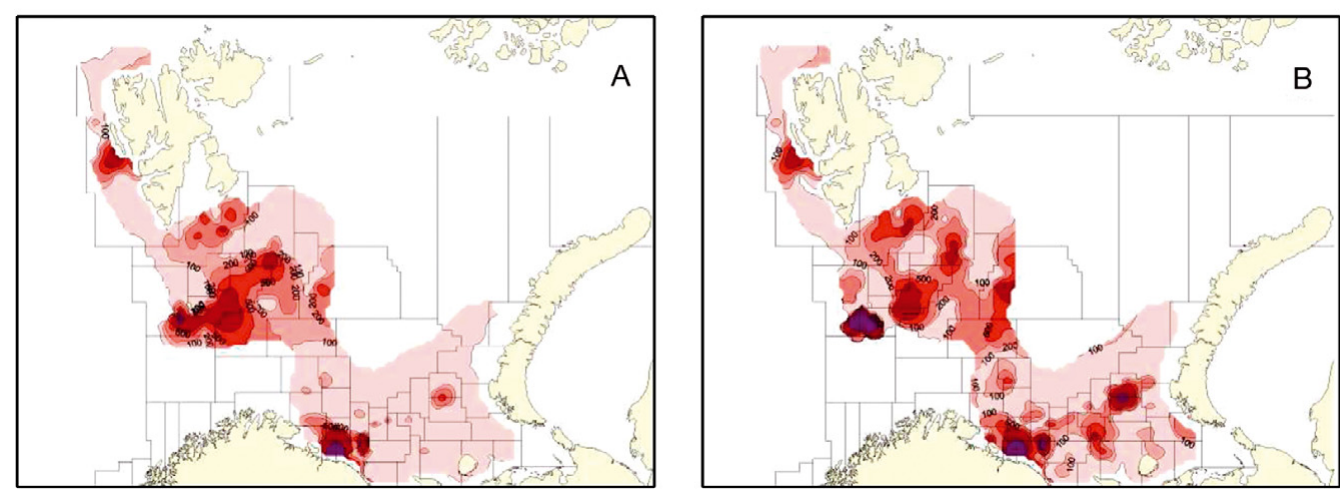

Ind. $1000 \mathrm{~m}^{-3}$

0
100
200
500
1000
5000
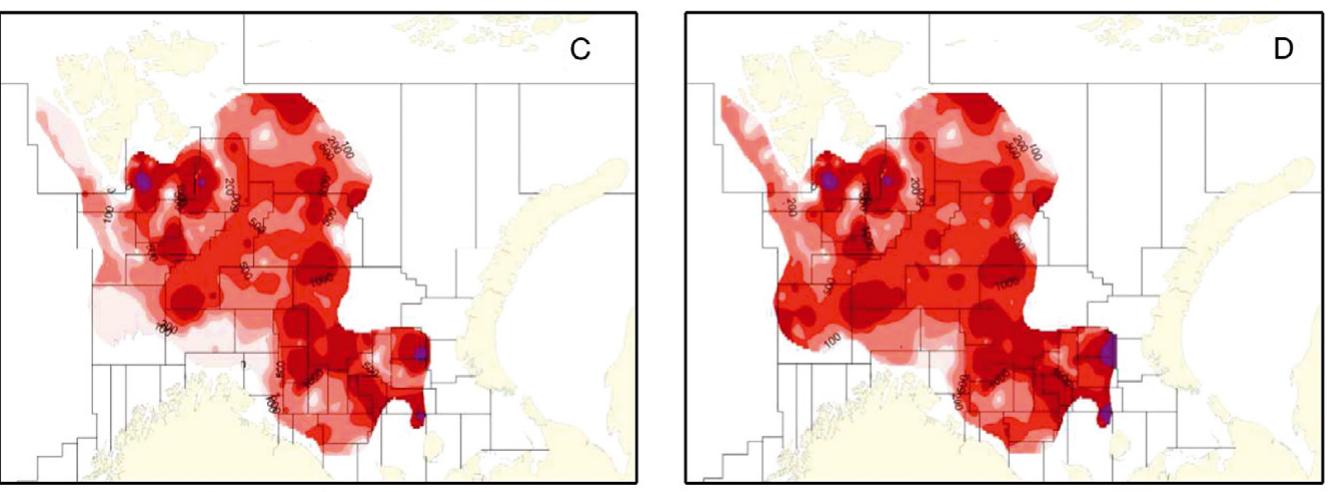

5000

Fig. 3. Euphausiid distributions in (A,B) very cold (1978) and (C,D) very warm (2007) years. (A,C) Thysanoessa inermis and $(\mathrm{B}, \mathrm{D})$ total euphausiid abundance. Densities (ind. $1000 \mathrm{~m}^{-3}$ ) indicated by color scale 
areas in September and even into October (Fig. 4). Extended feeding into October made up for late initiation of zooplankton development due to cold conditions. Late in the feeding season, euphausiids comprised around 30 to $50 \%$ of the capelin diet, and SFI reached as high as $1120 \%$ on the Persey Elevation (Fig. 4). Farther to the east in the Novaya Zemlya Shallows, feeding was not intense, and hyperiids (Themisto spp.) joined euphausiids as main dietary components during October (Fig. 4). Feeding was also relatively low north of $78^{\circ} \mathrm{N}$ in 1978.

In the moderately warm year 2002, capelin were dispersed more to the north, with the most intensive feeding between $78^{\circ}$ and $80^{\circ} \mathrm{N}$ (reaching an SFI of 500 to $600 \%$ oo on the Persey Elevation and south of Franz Josef Land (Fig. 5A). Copepods made up a large part of the capelin diet, but euphausiids were more common further north and for larger size classes (15.1 to $19 \mathrm{~cm}$ ) of fish. Feeding intensity was low in the Novaya Zemlya Shallows in mid-September, where hyperiids and other plankton formed the diets of mostly small $(<13 \mathrm{~cm})$ fish. The moderately warm year 2003 was characterized by lower feeding intensity of capelin and a displacement of areas of intensive feeding to the south. Only in the southern parts of Persey Elevation, just north of Central Elevation, did feeding intensity reach levels nearly comparable to 2002 (Fig. 5B). Diets here were mainly composed of copepods in smaller fish and hyperiids (up to $50 \%$ of diet) in larger ( $>13.1$ $\mathrm{cm}$ ) fish. Further north, capelin fed poorly (low SFI), but on euphausiids, while in the west feeding was even lower and included a mixture of copepods, euphausiids, and hyperiids (Fig. 5B). Because of a delayed and extended reproductive season for copepods in 2003 (Orlova et al. in press), capelin continued feeding well into October in some regions.

The very warm years of 2006 and 2007 were characterized by a range of feeding intensity by the widespread capelin. In 2006, feeding intensity was low ( \pm SFI 175 to $250 \%$ o) in the Zuidkap Deep, but reached more than $600 \%$ o in the Bear Island eastern slope area (Fig. 6A). In both locations, larger fish generally supplemented their copepod diets with significant quantities of euphausiids, whereas small fish fed nearly exclusively on copepods. Only larger fish were found in the northeastern parts of the Barents Sea, in the Persey Elevation and the Novaya Zemlya Shallows, and fed at moderate intensities (mean SFI around $200 \%$ o). These individuals fed primarily on euphausiids and copepods, with hyperiids forming a significant dietary fraction in the Novaya Zemlya Shallows (Fig. 6A).

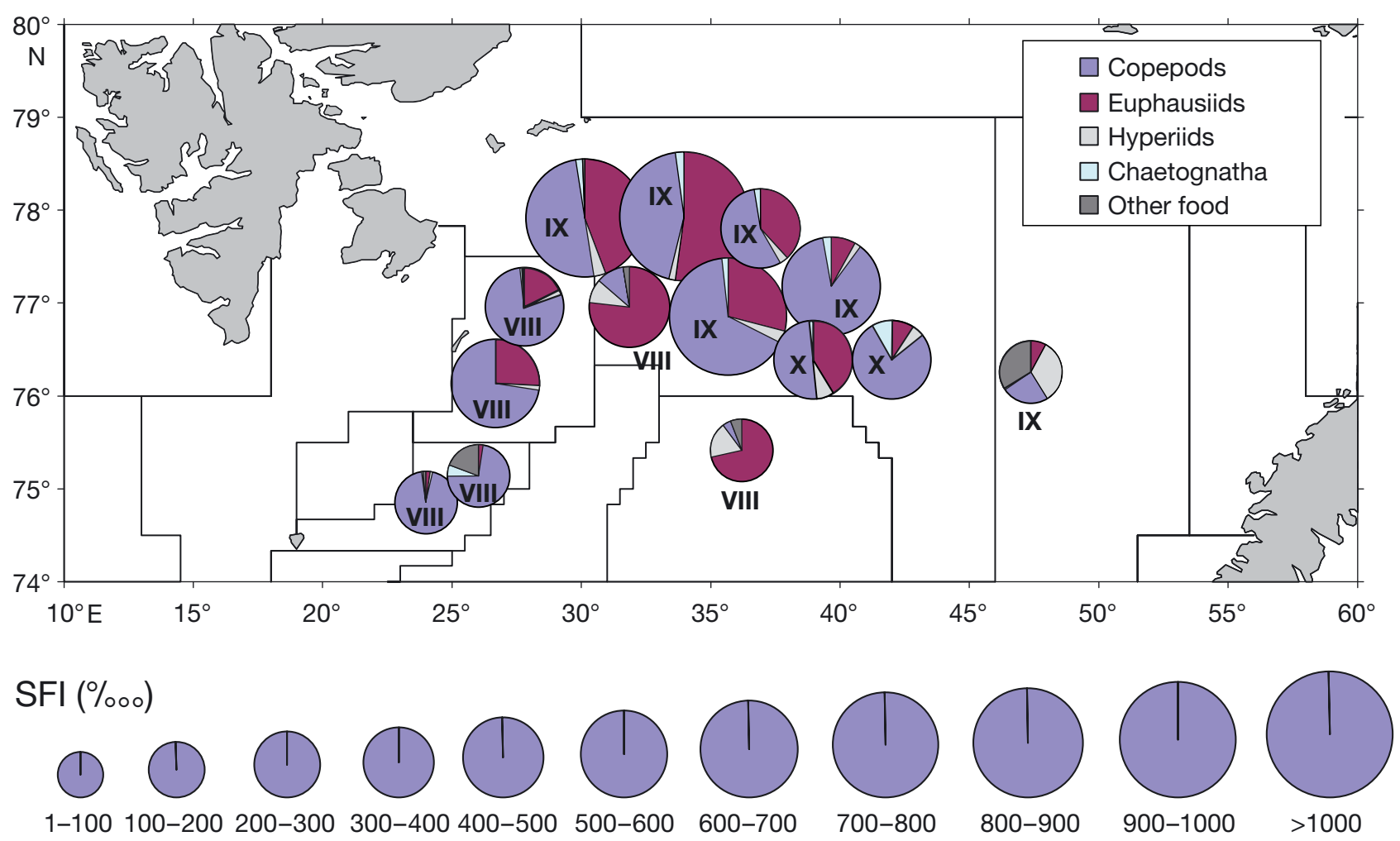

Fig. 4. Mallotus villosus. Capelin feeding intensity and dietary composition in a very cold year (1978). Size of circle indicates stomach fullness index (SFI, \%oo) and shading of each circular chart indicates mean percentage (by mass) contribution of each prey group. All size classes are combined into one circular chart per station. Roman numeral in each circle indicates sampling month 

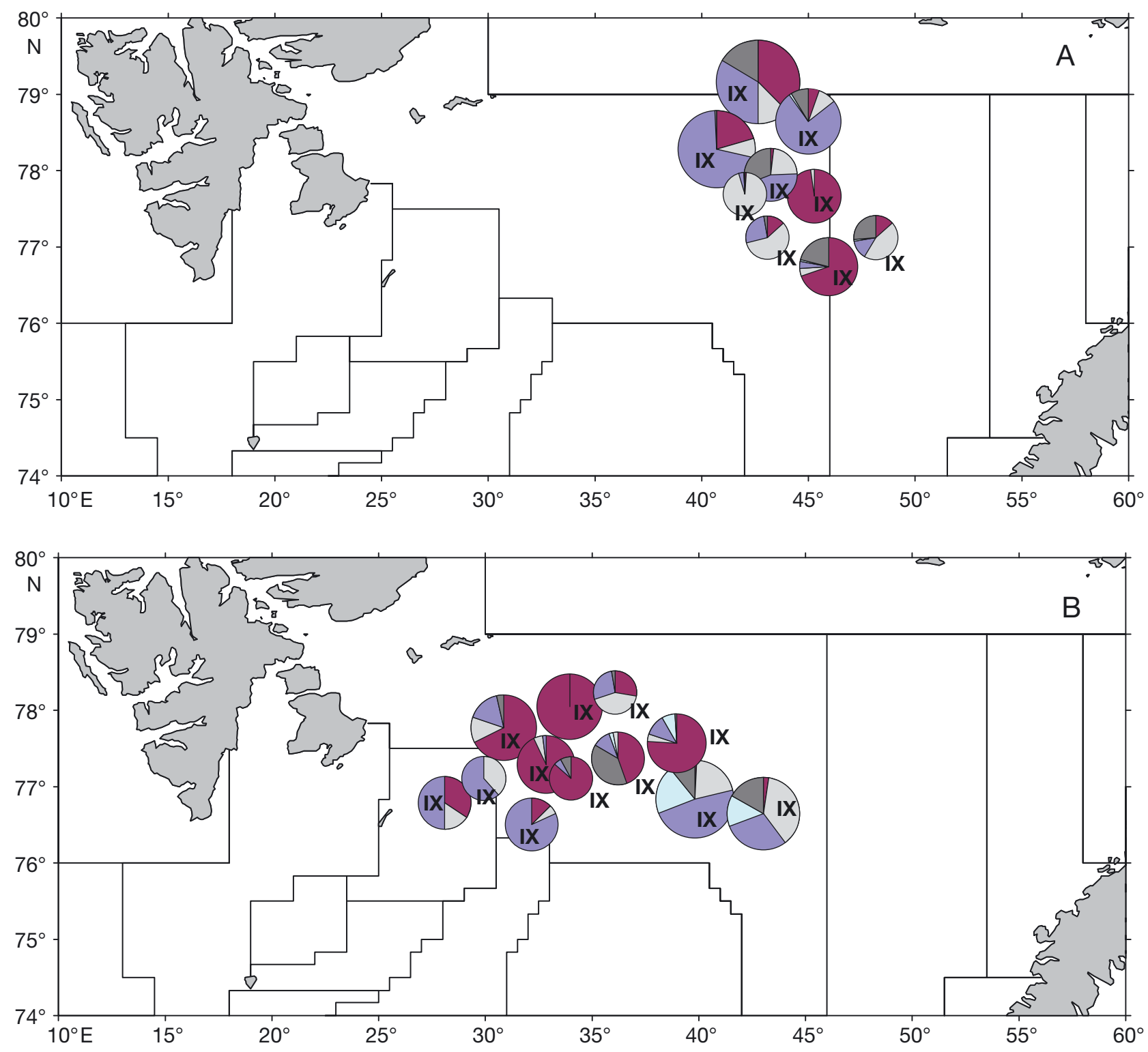

Fig. 5. Mallotus villosus. Capelin feeding intensity and dietary composition in the moderately warm years (A) 2002 and (B) 2003. Symbol size and diets as in Fig. 4

In 2007, feeding was widespread, and quite intense throughout the central and eastern areas north of $76^{\circ} \mathrm{N}$ (Fig. 6B). Below $76^{\circ} \mathrm{N}$ in the Persey Elevation and Novaya Zemlya Shallows, fish fed poorly, and mostly on euphausiids and the appendicularian Oikopleura sp., but further north, late (copepodite stage CV, adult female) stages of Calanus glacialis (and to a lesser extent $C$. finmarchicus) formed the largest part of the diets of most fish sampled. These were supplemented with chaetognaths (Sagitta sp.) and hyperiids in the east, and euphausiids in the central areas, where SFI was as high as $950 \%$, with euphausiids making up nearly $75 \%$ of the diet (Fig. 6B). Far to the east in the
Admiralty Peninsula area, capelin fed moderately on Calanus spp. and chaetognaths. North of Spitzbergen, capelin fed at moderate intensity on Calanus spp., euphausiids, and other food.

\section{Fat content of capelin}

Unequal distributions of fish among years and regions made it impossible to analyse all data in a single test. Despite this, some striking results were clear from our statistical analyses. The 3-way ANOVA indicated that region, year, and the region $\times$ year interac- 


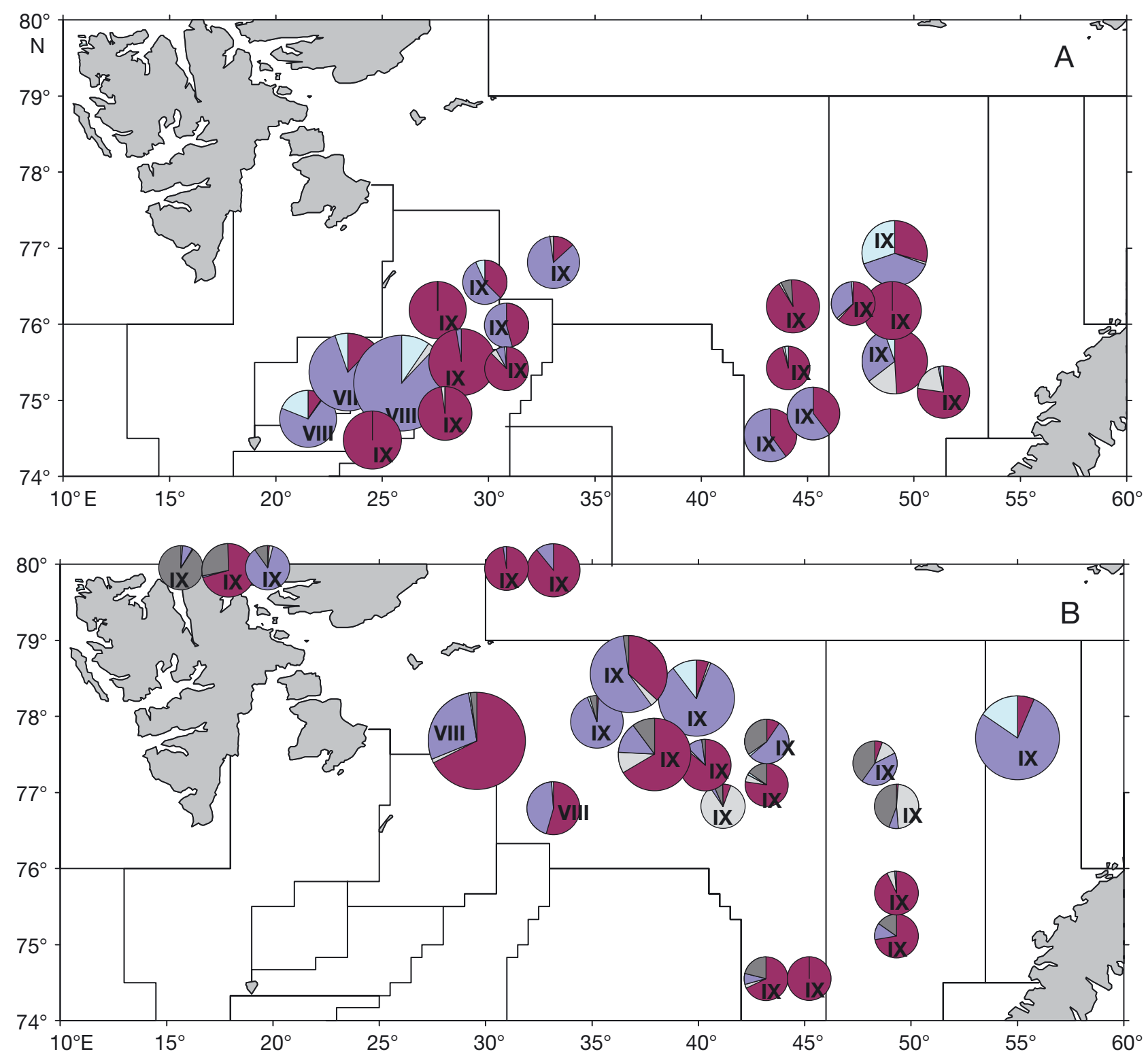

Fig. 6. Mallotus villosus. Capelin feeding intensity and dietary composition in the very warm years (A) 2006 and (B) 2007 . Symbol size and diets as in Fig. 4

tion were significant $(\mathrm{p}<0.01)$, whereas size class and all other interaction terms were highly non-significant (Table 2). Neumann-Keuls post hoc testing indicated that average fat content in $2002(10.6 \%)$ was greater than that in 2006 (9.2\%) and 2007 (7.5\%), which were not significantly different from each other. Capelin collected from the northeastern region displayed higher fat content than those from the central region. The 1-way ANOVAs allowed us to focus on interannual changes within a region, or among regions for a single year; and both of these analyses permitted use of the largest size class of capelin. Within the central region, fat content was again higher in 2002 (10.6\%) than in 2006 (8.4\%), and was also higher in 2006 than in either $2003(7.4 \%)$ or $2007(7.1 \%)$, the 2 latter years not being distinguishable from each other (Tables 2 \& 3). Finally, fish from the northeastern region had significantly higher fat levels $(10.1 \%)$ than those from either the northwestern $(8.8 \%)$ or central $(8.4 \%)$ regions in 2006 (Tables $2 \& 3$ ).

Fat content in 1978 generally ranged from 3 to $8 \%$ in the northwestern region in late August, with one high value of $16.6 \%$ around Hopen Island. On the Persey Elevation (central region), values were 5.7 to $8 \%$, whereas fat content was predictably highest in the northeastern region (Novaya Zemlya Shallows) at 9.4 to $16 \%$. 
Table 2. Statistical analyses on fat content of capelin Mallotus villosus. (A) 3-way factorial ANOVA for capelin fat content data for 2002, 2006, and 2007 in the central and northeastern regions. Only 13.1 to $17.0 \mathrm{~cm}$ standard length (SL) fish were included in analysis. Size classes are in $2 \mathrm{~cm}$ increments within this range. Neumann-Keuls main effects comparison test: $2002>2006=2007$; northeastern $>$ central. (B) 1-way ANOVA testing the effect of year $(2002,2003,2006,2007)$ on capelin (13.1-19.0 cm SL) collected from the central region. Neumann-Keuls multiple comparison test results: $2002>2006$ $>2003=2007$. (C) 1 -way ANOVA testing the effect of region on capelin (13.1-19.0 cm SL) collected in 2006. NeumannKeuls multiple comparison test results: northeastern > northwestern $=$ central. $\mathrm{p}$-values in bold indicate statistical significance

\begin{tabular}{|lccc|}
\hline Effect & df & $F$ & \multicolumn{1}{c|}{$\mathrm{p}$} \\
\hline (A) 3-way factorial ANOVA & & & \\
Region & 1 & 15.02 & $\mathbf{< 0 . 0 0 0 2}$ \\
Year & 2 & 119.0 & $\mathbf{< 0 . 0 0 0 1}$ \\
Size class & 1 & 1.84 & $>0.17$ \\
Region $\times$ year & 2 & 5.15 & $<\mathbf{0 . 0 0 7}$ \\
Region $\times$ size class & 1 & 0.05 & $>0.82$ \\
Year $\times$ size class & 2 & 0.14 & $>0.87$ \\
Region $\times$ year $\times$ size class & 2 & 0.86 & $>0.42$ \\
(B) 1-way ANOVA, effect of year & & & \\
Year & 3 & 47.14 & $<\mathbf{0 . 0 0 0 1}$ \\
(C) 1-way ANOVA, effect of region & & & \\
Region & 2 & 11.8 & $<\mathbf{0 . 0 0 0 1}$ \\
\hline
\end{tabular}

Best-fit models from multiple regression analyses included capelin biomass and the NAO index, accounting for $28.4 \%$ of the interannual variability in maximum fat content (adjusted $\mathrm{R}^{2}$ ) according to the equation: maximum fat content $=7.8+(0.92 \times$ capelin biomass $)-(1.2 \times \mathrm{NAO})$. These 2 explanatory variables were essentially uncorrelated $(r=-0.01)$, and the Kola anomaly was correlated with the NAO with a regression coefficient of 0.45 .

\section{DISCUSSION}

\section{Determinants of capelin feeding}

Feeding intensity and dietary components varied significantly among years and among regions within each year (Figs. 4-6). In general, SFIs were highest in the Persey Elevation area in most years studied, but also in the Hopen $(1978,2007)$, Bear Island/Spitsbergen Banks (2006), and the Novaya Zemlya Shallows (2007) areas during some years. Persey Elevation and the Novaya Zemlya Shallows are known to be key feeding areas for Barents Sea capelin (Ozhigin \& Luka 1985, Gjøsæeter 1998), especially in late summerautumn as fish migrate north and east following the ice edge and distribution of developing zooplankton. The highest overall feeding intensity (SFI) was seen in the
Table 3. Mallotus villosus. Fat content in muscle tissue (\%, mean \pm SD) of capelin of different size classes in the central, northeastern, and northwestern regions of the Barents Sea in August-September 2002, 2003, 2006, and 2007. N: number of fish

\begin{tabular}{|c|c|c|c|c|}
\hline Year & Area & Size $(\mathrm{cm})$ & $\mathrm{N}$ & Fat content $(\%)$ \\
\hline \multirow[t]{7}{*}{2002} & \multirow[t]{4}{*}{ Central } & $11.1-13.0$ & 19 & $10.6 \pm 2.1$ \\
\hline & & $13.1-15.0$ & 50 & $10.7 \pm 2.4$ \\
\hline & & $15.1-17.0$ & 43 & $10.6 \pm 3.4$ \\
\hline & & $17.1-19.0$ & 10 & $10.3 \pm 2.1$ \\
\hline & \multirow[t]{3}{*}{ Northeastern } & $13.1-15.0$ & 51 & $10.8 \pm 1.2$ \\
\hline & & $15.1-17.0$ & 38 & $10.4 \pm 1.6$ \\
\hline & & $17.1-19.0$ & 5 & $9.5 \pm 0.9$ \\
\hline \multirow[t]{4}{*}{2003} & \multirow[t]{4}{*}{ Central } & $9.1-11.0$ & 17 & $5.2 \pm 0.5$ \\
\hline & & $11.1-13.0$ & 10 & $6.1 \pm 1.4$ \\
\hline & & $13.1-15.0$ & 20 & $7.5 \pm 0.9$ \\
\hline & & $15.1-17.0$ & 21 & $7.4 \pm 1.3$ \\
\hline \multirow[t]{10}{*}{2006} & \multirow[t]{2}{*}{ Central } & $15.1-17.0$ & 13 & $8.5 \pm 1.9$ \\
\hline & & $17.1-19.0$ & 3 & $8.0 \pm 1.6$ \\
\hline & \multirow[t]{3}{*}{ Northeastern } & $13.1-15.0$ & 21 & $10.3 \pm 1.8$ \\
\hline & & $15.1-17.0$ & 39 & $9.8 \pm 2.0$ \\
\hline & & $17.1-19.0$ & 10 & $10.7 \pm 1.6$ \\
\hline & \multirow[t]{5}{*}{ Northwestern } & 9.1-11.0 & 38 & $5.4 \pm 1.3$ \\
\hline & & $11.1-13.0$ & 62 & $5.9 \pm 1.3$ \\
\hline & & $13.1-15.0$ & 42 & $8.5 \pm 2.1$ \\
\hline & & $15.1-17.0$ & 45 & $8.9 \pm 1.8$ \\
\hline & & $17.1-19.0$ & 10 & $9.3 \pm 1.6$ \\
\hline \multirow[t]{8}{*}{2007} & \multirow[t]{4}{*}{ Central } & $11.1-13.0$ & 8 & $4.1 \pm 0.8$ \\
\hline & & $13.1-15.0$ & 53 & $7.4 \pm 2.0$ \\
\hline & & $15.1-17.0$ & 43 & $6.7 \pm 2.0$ \\
\hline & & $17.1-19.0$ & 4 & $6.6 \pm 1.0$ \\
\hline & \multirow[t]{4}{*}{ Northeastern } & $11.1-13.0$ & 5 & $6.0 \pm 1.0$ \\
\hline & & $13.1-15.0$ & 55 & $8.1 \pm 1.3$ \\
\hline & & $15.1-17.0$ & 62 & $8.0 \pm 1.4$ \\
\hline & & $17.1-19.0$ & 12 & $8.4 \pm 1.2$ \\
\hline
\end{tabular}

very cold year of 1978 , while it was low to moderate over most of the capelin range during each of the moderate years, and highly variable but locally intense in the very warm years 2006 and 2007. Many factors likely contributed to this, including hydrographic conditions affecting zooplankton populations, presence of competitors, and migration patterns.

Spatially, the feeding intensity varied with capelin distribution. In the abnormally cold year 1978, fish did not take full advantage of food potential in the northern areas since the feeding migration was late (August) and the feeding period was short (only September). Low feeding in the north and far east in 2003 was also probably due to a much more restricted distribution in 2003 compared to other years (Fig. 2). In addition, overlap of capelin in time and space with zooplankton food is a critical determinant of both feeding intensity and diet composition. In general, capelin tend to feed on different prey species in approximate proportion to their availability in the environment, mainly selecting on the basis of size (Gjøsæter 1998). Thus the diet of young capelin often includes smaller copepod 
species (e.g. Pseudocalanus sp.) and early copepodites of Calanus spp., while larger fish feed predominantly on larger copepods, euphausiids, and hyperiid amphipods (O'Driscoll et al. 2001, Gjøsæter et al. 2002, Orlova et al. 2002a, 2009a). This view may be oversimplified, however, as even young fish select for later stages (such as stage CV and adults) of Calanus glacialis, despite smaller stages (CII, CIII) dominating the population (Orlova et al. in press). If such discrepancies are common they may reflect active selection for the more energetically beneficial lipid-rich developmental stages (Falk-Petersen et al. 2009) or, alternatively, increased encounter rates with the more conspicuous larger copepodite stages (Aksnes \& Utne 1997, Eiane et al. 2002). Either way, indications of prey selection suggest that simple diet models based on prey communities alone (e.g. Huse \& Ellingsen 2008) may be limiting studies of capelin dynamics and the ecological significance of the highly variable Barents Sea capelin stock (Gjøsæter et al. 2009a).

Even when Calanus glacialis is not the most numerically abundant prey item, it can frequently dominate the biomass because of its large size (Orlova et al. 2009b, in press). This dietary dominance of C. glacialis requires a broad northerly distribution of capelin and climatic conditions that favor coincident distribution (Daase et al. 2007) and rapid development (e.g. FalkPetersen et al. 2009) of C. glacialis. In addition, older ( 2 to 3 yr) capelin that feed in subsurface layers after maturing copepods have descended for the year can also show such dominance of $C$. glacialis in their diets (e.g. Orlova et al. 2002b).

Diet composition of capelin in the present study varied considerably in time and space. Spatial and interannual variations in zooplankton biomass in the Barents Sea can vary by an order of magnitude (Arashkevich et al. 2002). This variability could clearly impact capelin diets. The near absence of large copepods from extensive areas of the Barents Sea in 2004 was also reflected in capelin diets (Orlova et al. 2009a). We found a similar pattern in the relationship between euphausiid abundance and their presence in capelin diets in 1978 and 2007 (Figs. 3 \& 6B). The role of climate variation in the advection of this Atlantic euphausiid into the Barents Sea (Zhukova et al. 2009) suggests a direct link between diet and climate. Alternatively, krill abundance in the Barents Sea has also been shown to be inversely related to capelin population size (Dalpadado \& Skjoldal 1996), and high krill levels in 2007 could also be due to several preceding years of low capelin abundances.

Spatial patterns in diet may also be related to sizespecific migration patterns (Huse \& Ellingsen 2008). Only large, mature fish (13.1 to $19 \mathrm{~cm})$ migrated to the Novaya Zemlya Shallows feeding area in 2006, and that is reflected in a high proportion of euphausiids in their diet (Fig. 6A). This feeding area is also the site of abundant hyperiid amphipods in the zooplankton community (Orlova et al. in press), and this is reflected in the role these species play in capelin diet here compared to other areas of the Barents Sea (Figs. 4-6). Northwestern areas around Bear and Hopen Islands are feeding grounds for fishes of mixed ages, and diets here are often characterized by a variety of diet compositions, especially in 2003 and 2006 (Figs. 5B \& 6A).

Zooplankton abundance patterns, however, are not the only factors that influence diet and feeding intensity. Despite seemingly good feeding conditions in the Barents Sea in 2006 and 2007, when capelin distribution overlapped that of their preferred prey in nearly all areas (Orlova et al. in press), feeding intensity was mixed. After relatively low abundances in 2003-2005, the capelin population increased by a factor of 5 between 2005 and 2007, suggesting that intraspecific competition may have negatively impacted capelin feeding. This has also been cited as an explanation for the negative correlation between size of $2 \mathrm{yr}$ old capelin (length, mass) and population size (Gjøsæter 1998). Capelin, when abundant, are able to deplete local zooplankton populations in a matter of days (Hassel et al. 1991), perhaps leading to increased feeding migrations in years of high population size. This suggests that capelin condition should suffer in years of large stock size. However, our data on variability in capelin fat content (Table 1) do not support this mechanism: only 2 of the 6 years with the poorest capelin condition (upper range of fat content $<10 \%$ ) occurred when the stock size was intermediate to high $(1992,2007)$, while 4 years $(1987,2003-2005)$ occurred when the capelin stock size was low $\left(<10^{6} t_{\text {; }}\right.$ Gjøsæter et al. 2009a, b). Further, capelin biomass was positively correlated with capelin fat content. Thus our findings suggest that density-dependent mechanisms such as intraspecific competition may not be a main determinant of capelin condition. Competition with other species, such as polar cod Boreogadus saida, has also been shown to be important in leading to lower feeding intensity and condition in capelin in the Barents Sea (Orlova et al. 2002b, 2009a). 0-group cod Gadus morhua and haddock Melanogrammus aeglefinus mainly consume copepods and euphausiids (Dalpadado et al. 2009), and thus may further limit food availability in this area. Inter- and intraspecific competition may also lead to increases in the dietary share of less preferred food such as chaetognaths, pteropods, and Oikopleura (e.g. Orlova et al. 2009a). Climatic conditions may, then, indirectly affect capelin feeding through its impact on population sizes and distributions of capelin, polar cod, and other gadoids. In turn, the population sizes of capelin and potential competitors may affect capelin condition. 


\section{Determinants of capelin fat content}

Accumulation of fat is critical for capelin survival during winter when food supply may be limited, and for reproduction in mature fish. In general, capelin need to reach a fat content (in muscle) of $7.5 \%$ by the end of the autumn feeding period to facilitate the following year's reproduction (Orlova et al. 2002b). This limit has been suggested to vary from 5.6-6.2\% for females to $8.5-9.3 \%$ for males (Oganesyan \& Dvinan 1988). In addition, fatness of capelin is directly linked to their value for higher predators, such as Atlantic cod, seabirds, and marine mammals. Small variations in fat content of prey can be critical for reproduction and survival of Arctic top predators (e.g. Karnovsky et al. 2003), and this may act in combination with variations in stock size, distribution, and age structure of capelin to determine dynamics of their predators.

Copepods form the basis of capelin diet in the Barents Sea. Poor copepod resources for capelin, such as in 2004, co-occurred with low capelin fat content, leading to values below the level required for adequate reproduction in the following year (Table 1) (Orlova et al. 2009a). Active selection by capelin for species or size, however, can optimize fat intake. The Arctic Calanus glacialis is considerably larger and contains more lipid than the Atlantic-boreal C. finmarchicus (Scott et al. 2002). As shown above, capelin appears to select for C. glacialis and for larger (and more fat-rich) life stages. For this selection to occur, however, Arctic copepods must reach appropriate developmental stages and capelin must overlap in time and space with these zooplankton. This, in turn, depends on phytoplankton bloom dynamics, abundance of polar cod, and age structure of the capelin population (see Orlova et al. in press for more details). For example, the warm to very warm year of 1992 in the Barents Sea was characterized by early phytoplankton blooms, early development and descent of zooplankton, and abundant polar cod. This resulted in poor body condition in capelin despite high zooplankton biomass (Table 1; Orlova et al. 2002a,b).

Euphausiids and hyperiid amphipods supplement copepods in capelin diets, both extending the feeding season (both earlier and later than feeding on copepods; e.g. Gjøsæter 1998) and providing high energy food for building fat reserves (e.g. Orlova et al. 2002b, 2009a). In combination, these 2 zooplankton groups can comprise 70 to $99 \%$ of capelin energy intake across all 4 seasons in some locations (Lund 1981 in Gjøsæeter 1998). Hyperiid amphipods generally increase in importance in capelin diets toward the eastern parts of the Barents Sea (Fig. 4-6), and the high interannual variability in capelin and euphausiid abundance and distribution (Figs. $2 \& 3$ ) implicate climate as one factor in determining capelin fat content. The combination of the high proportion of older fish completing annual migrations to the northeastern region, the generally later period in the season when this occurs, and the higher proportion of hyperiid amphipods and krill in the diet of fish in this area resulted in the general trend toward highest fat content observed in the northeastern region (Table 3, results of fat content from 1978 fish).

By influencing the length of zooplankton reproduction and development seasons (cf. Orlova et al. 2002a, in press), climate variability can also influence the duration of suitable feeding conditions for capelin. Late or prolonged spawning of zooplankton resulted in capelin feeding well into October (warm 1983, Orlova et al. 2005; warm 1984, Orlova et al. 2002b; moderate 2003, see 'Results'). Fat content in 1984 and 1985 were, however, quite high, perhaps suggesting that the Barents Sea capelin is well adapted to such levels of interannual variability in ocean climate. Fat levels in 2003 were the lowest (along with 2007) of the years presented here (Table 2). This suggests that climatic conditions act in a complex manner, influencing multiple factors including zooplankton development and advection and capelin migration patterns, any of which can affect capelin fat content.

\section{Role of climatic variation in ecosystem function}

Climatic condition, through its impacts on many of the important determinants of capelin feeding and fat accumulation, both directly and indirectly influences the value of capelin in the ecosystem. Our summary of fat content data suggests that in warm years (1992, 2004-2007), Barents Sea capelin generally have reduced fat content in muscle, and in 3 of those years most of the stock remained below the fat level suggested to be critical for successful reproduction (Table 1). Multiple regression analysis for 15 years of data indicated that capelin biomass and the NAO climatic index explained more than $28 \%$ of the interannual variability in maximum fat content. This suggests that climatic conditions partly determine feeding conditions for capelin, and may influence population biomass accumulation and fat content simultaneously. Whereas the explanatory power of these 2 factors is not all that strong, it is slightly higher than the variance in Barents Sea zooplankton biomass explained by the NAO using capelin biomass as a threshold value (Stige et al. 2009). Clearly, climate affects both capelin biomass and condition, as well as the biomass of its main prey, but in a complex manner.

Fat content was low in 1987, but high in 1984 (Table 1), this pattern running counter to what a simple climatic 
explanation would predict. In fact, excluding the 1984 data from the regression analyses increased the adjusted $R^{2}$ from 0.284 to 0.57 . We suggest that other factors such as those described above may interact to determine the final condition of capelin. Low capelin abundance in areas traditionally important for capelin fattening may have resulted in lower fat content in 2003, while under similar climatic conditions in 2002 the distribution of fish was broader, especially in the northeastern region. Statistical models have suggested that many important interactions affecting population sizes of capelin and their prey act with lag times of 2 to 4 yr (Stige et al. 2009).

Over long periods of time, climate change may result in increased primary productivity and significantly alter the Barents Sea zooplankton community by reducing Calanus glacialis abundance by $50 \%$, while only modestly increasing the $C$. finmarchicus population (Ellingsen et al. 2008). This scenario could have strong negative implications for capelin feeding as spatial distribution and age structure of C. finmarchicus does not seem to be related to water temperature in the Barents Sea (Tande et al. 2000). This conclusion by Tande et al. (2000) was reached based on data from only the upper $50 \mathrm{~m}$ of the water column. In warmer years, however, zooplankton develops faster and descends to lower layers, and samples from only the top $50 \mathrm{~m}$ may miss high zooplankton concentrations (see Orlova et al. 2009b). In the western North Atlantic, climatic conditions have resulted in capelin rapidly changing distributional patterns and spawning locations (Rose 2005), but this also suggests that relaxation in climate warming may see a return to 'normal' distributions. Temperature effects on capelin distributions have been suggested for the Barents Sea as well (Loeng et al. 1983; Fig. 2), and northward shifts in distributions of capelin predators are also expected with climate warming in the Barents Sea (e.g. Dalpadado et al. 2009). In a recent simulation study (Huse \& Ellingsen 2008), further climate warming of the Barents Sea is predicted to shift the distribution pattern of Barents Sea capelin eastwards, partly due to establishments of new spawning grounds off Novaya Zemlya. Climate variation, therefore, can affect the pelagic ecosystem, in which capelin play such a key role, in both top-down (trophic cascades; Carscadden et al. 2001) and bottom-up (food supply) manners. The precise impacts of climate warming and the results of direct and indirect ecological interactions are complex and difficult to predict.

The present study strongly suggests that the condition (fat content) of Barents Sea capelin stock is related to climate variability. However, the long-term changes in many factors such as the distribution and abundance of plankton, the feeding capelin stock and its competi- tors and predators, and fishing effort are too complex for their integrated effects on capelin condition to be simply generalized from climate-to-ecosystem models. Indeed, climate effects may be overwhelmed when some factors, such as predation pressure, are particularly strong (Stige et al. 2009). Increased human activity in the Arctic due to climate warming (shipping, fishing, petroleum exploration, and transport) may also impact both capelin and their zooplankton prey. Long time-series from the Barents Sea, therefore, are important since data from only a few years may lead to predictions that miss many important factors, thereby resulting in poor predictions of future fishery stock condition.

Ackowledgements. The authors acknowledge the scientific personnel and ships' crews at PINRO and the Norwegian Institute of Marine Research, Bergen, for leading cruises where the samples were collected. Financial support has been provided by PINRO, Akvaplan-niva, and Statoil. We thank the 3 anonymous reviewers for their comments.

\section{LITERATURE CITED}

Aksnes DL, Utne ACW (1997) A revised model of the visual range in fish. Sarsia 82:137-147

Anonymous (2002) Survey report from the joint Norwegian/ Russian ecosystem survey in the Barents Sea AugustOctober 2002. IMR-PINRO Joint Rep Ser No 2/2002, Institute of Marine Research, Bergen, Norway

Anonymous (2003) Survey report from the joint Norwegian/ Russian ecosystem survey in the Barents Sea AugustOctober 2003. IMR-PINRO Joint Rep Ser No 2/2003, Institute of Marine Research, Bergen, Norway

Anonymous (2008) Survey report from the joint Norwegian/ Russian ecosystem survey in the Barents Sea AugustSeptember 2007. IMR-PINRO Joint Rep Ser No 1/2008, Institute of Marine Research, Bergen, Norway

Arashkevich E, Wassmann P, Pasternak A, Wexels Riser C (2002) Seasonal and spatial changes in biomass, structure, and development progress of the zooplankton community in the Barents Sea. J Mar Syst 38:125-145

> Bogstad B, Gjøsæter H (2001) Predation by cod (Gadus morhua) on capelin (Mallotus villosus) in the Barents Sea: implications for capelin stock assessment. Fish Res 53:197-209

Boitsov VD (2008) Long-term fluctuations of air temperature in the North Atlantic and the North European basin. Proc Russ Geogr Soc 140:6-11

Carscadden JE, Frank KT, Leggett WC (2001) Ecosystem changes and the effects on capelin (Mallotus villosus), a major forage species. Can J Fish Aquat Sci 58:73-85

Daase M, Vik JO, Bagøien E, Stenseth NC, Eiane K (2007) The impact of advection of Calanus near Svalbard: statistical relations between salinity, temperature and copepod abundance. J Plankton Res 29:903-911

> Dalpadado P, Skjoldal HR (1996) Abundance, maturity and growth of the krill species Thysanoessa inermis and $T$. longicaudata in the Barents Sea. Mar Ecol Prog Ser 144:175-183

> Dalpadado P, Bogstad B, Eriksen E, Rey L (2009) Distribution and diet of 0-group cod (Gadus morhua) and haddock 
(Melanogrammus aegelfinus) in the Barents Sea in relation to food availability and temperature. Polar Biol 32: 1583-1596

Dolgov A (2002) The role of capelin (Mallotus villosus) in the foodweb of the Barents Sea. ICES J Mar Sci 59:1034-1045

Dommasnes A, Loeng H, Monstad T (1979) Capelin investigations in the Barents Sea during autumn 1978. Fisken Havet 1979:17-30 (in Norwegian)

Eiane K, Aksnes DL, Ohman MD, Wood S, Martinussen MB (2002) Stage specific mortality of Calanus spp. under different predation regimes. Limnol Oceanogr 47:636-645

Ellingsen $\mathrm{IH}$, Dalpadado P, Slagstad D, Loeng H (2008) Impact of climatic change on the biological production in the Barents Sea. Clim Change 87:155-175

Falk-Petersen S, Hopkins CCE, Sargent JR (1990) Trophic relationships in the pelagic food web. In: Barnes M, Gibson RN (eds) Trophic relationships in the marine environment. Aberdeen University Press, Aberdeen, p 315-333

Falk-Petersen S, Hagen W, Kattner G, Clarke A, Sargent JR (2000) Lipids, trophic relationships and biodiversity in Arctic and Antarctic krill. Can J Fish Aquat Sci 57: 178-191

Falk-Petersen S, Mayzaud P, Kattner G, Sargent JR (2009) Lipids and life strategy of Arctic Calanus. Mar Biol Res 5:18-39

Folkow LP, Haug T, Nilssen KT, Norday ES (2000) Estimated food consumption of minke whales (Balaenoptera acutirostrata) in northeast Atlantic waters in 1992-1995. NAMMCO Sci Pub 2:65-80

Gjøsæter H (1998) The population biology and exploitation of capelin (Mallotus villosus) in the Barents Sea. Sarsia 83:453-496

Gjøsæeter H, Bogstad B (1998) Effects of the presence of herring (Clupea harengus) on stock-recruitment relationship of Barents Sea capelin (Mallotus villosus). Fish Res 38:57-71

Gjøsæter H, Loeng H (1987) Growth of Barents Sea capelin, Mallotus villosus, in relation to climate. Environ Biol Fishes 20:293-300

Gjøsæter H, Dalpadado P, Hassel A (2002) Growth of Barents Sea capelin (Mallotus villosus) in relation to zooplankton abundance. ICES J Mar Sci 59:959-967

Gjøsæter H, Bogstad B, Tjelmeland S (2009a) Ecosystem effects of the three capelin stock collapses in the Barents Sea. Mar Biol Res 5:40-53

Gjøsæter H, Dommasnes A, Falkenhaug T, Hauge M, Johannesen E, Olsen E, Skagseth $\varnothing$ (eds) (2009b) Havets Ressurser og Miljø 2009. Fisken Havet, Suppl 1-2009, Institute of Marine Research, Bergen, Norway (in Norwegian)

Hassel A, Skjoldal HR, Gjøsæter H, Loeng H, Omli L (1991) Impact of grazing from capelin (Mallotus villosus) on zooplankton: a case-study in the northern Barents Sea in August 1985. Polar Res 10:371-388

Hjermann DØ, Ottersen G, Stenseth NC (2004a) Competition among fishermen and fish causes the collapse of Barents Sea capelin. Proc Natl Acad Sci USA 101:11679-11684

$>$ Hjermann DØ, Stenseth NC, Ottersen G (2004b) Indirect climatic forcing of the Barents Sea capelin: a cohort effect. Mar Ecol Prog Ser 273:229-238

- Hjermann DØ, Bogstad B, Eikeset AM, Ottersen G, Gjøsæter H, Stenseth NC (2007) Food web dynamics affect Northeast Arctic cod recruitment. Proc R Soc Lond B 274: 661-669

Hurrell JW (1995) Decadal trends in the North Atlantic oscillation: regional temperatures and precipitation. Science 269:676-679

Huse G, Ellingsen I (2008) Capelin migrations and climate change-a modelling analysis. Clim Change 87:177-197

Karnovsky NJ, Kwaśniewski S, Węsławski JM, Walkusz W, Beszczyńska-Moller A (2003) Foraging behavior of little auks in a heterogeneous environment. Mar Ecol Prog Ser 253:289-303

Lazarevsky AA (1955) Technochemical control in fish technology industry. Pischchepromizdat, Moscow (in Russian)

Loeng H, Nakken O, Raknes A (1983) The distribution of capelin in the Barents Sea in relation to the water temperature in the period 1974-1982. Fisken Havet 1983:1-17 (in Norwegian)

Lund A (1981) Food and feeding of capelin in the Barents Sea. MS thesis, Univ Bergen, Bergen, p 1-128 (in Norwegian)

Nilssen KT, Pedersen OP, Folkow L, Haug T (2000) Food consumption estimates of Barents Sea harp seals. NAMMCO Sci Pub 2:9-28

O'Driscoll RL, Parsons MJD, Rose GA (2001) Feeding of capelin (Mallotus villosus) in Newfoundland waters. Sarsia 86:165-176

Oganesyan SA, Dvinan MY (1988) Relationship between the rate of fish maturation and the intensity of their fat accumulation (exemplified by the Barents Sea capelin). In: Matishov GG (ed) Ecology and productivity and problems of mariculture of the Barents Sea. Proc 2nd all. Union Conf, Murmansk. PINRO Press, Murmansk, p 186-188

Orlova EL, Boitsov VD, Nesterova VN, Ushakov NG (2002a) Composition and distribution of copepods, a major prey of capelin in the central Barents Sea, in moderate and warm years. ICES J Mar Sci 59:1053-1061

Orlova EL, Ushakov NG, Nesterova VN, Boitsov VD (2002b) Food supply and feeding of capelin (Mallotus villosus) of different size in the central latitudinal zone of the Barents Sea during intermediate and warm years. ICES J Mar Sci 59:968-975

Orlova EL, Boitsov VD, Dolgov AV, Rudneva GB, Nesterova VN (2005) The relationship between plankton, capelin, and cod under different temperature conditions. ICES J Mar Sci 62:1281-1292

> Orlova EL, Dolgov AV, Rudneva GB, Oganin IA, Konstantinova LL (2009a) Trophic relations of capelin Mallotus villosus and polar cod Boreogadus saida in the Barents Sea as a factor of impact on the ecosystem. Deep-Sea Res II 56: 2054-2067

Orlova EL, Knutsen T, Dalpadado P, Berchenko I and others (2009b) Zooplankton. In: Stiansen JE, Korneev O, Titov O, Arneberg P (eds) Filin A, Hansen JR, Høines Å, Marasaev $\mathrm{S}$ (co-eds) Joint Norwegian-Russian environmental status 2008. Report on the Barents Sea Ecosystem, Part II. Complete report. IMR/PINRO Joint Report Series, p 201-211

Orlova EL, Boitsov VD, Nesterova VN (in press) The influence of hydrographic conditions on the structure and functioning of the trophic complex plankton - pelagic fishes - cod. PINRO Press, Murmansk

Ottersen G, Stenseth NC (2001) Atlantic climate governs oceanographic and ecological variability in the Barents Sea. Limnol Oceanogr 46:1774-1780

Ozhigin VK, Luka GI (1985) Some peculiarities of capelin migrations depending on thermal conditions in the Barents Sea. In: Gjøsæter H (ed) The proceedings of the Soviet-Norwegian symposium on the Barents Sea capelin. Institute of Marine Research, Bergen, p 135-147

Rose GA (2005) Capelin (Mallotus villosus) distribution and climate: a sea 'canary' for ecosystem change. ICES J Mar Sci 62:1524-1530

Scott CL, Kwasniewski S, Falk-Petersen S, Sargent JR (2002) Species differences, origins and functions of fatty alcohols and fatty acids in the wax esters and phospholipids of 
Calanus hyperboreus, C. glacialis and C. finmarchicus from Arctic waters. Mar Ecol Prog Ser 235:127-134

Stige LC, Lajus DL, Chan KS, Dalpadado P, Basedow SL, Berchenko I, Stenseth NC (2009) Climatic forcing of zooplankton dynamics is stronger during low densities of planktivorous fish. Limnol Oceanogr 54:1025-1036

Tande KS, Nilssen EM, Edvardsen A, Drobysheva S, Nesterova V, Tereschenko V (2000) Patterns in the variations of copepod spring and summer abundance in the northeastern Norwegian Sea and the Barents Sea in cold and warm years during the 1980s and 1990s. ICES J Mar Sci $57: 1582-1591$

Ushakov NG (2000) Biological grounds of rational fishery for capelin in the Barents Sea. PhD dissertation, University of

Editorial responsibility: Matthias Seaman,

Oldendorf/Luhe, Germany
Moscow (in Russian with English Abstract)

Ushakov NG, Ozhigin VK (1987) Formation of capelin year class abundance and features of their juvenile distribution affected by oceanological conditions. In: Loeng (ed) The effect of oceanological conditions on the distribution and dynamics of commercial fish populations in the Barents Sea. Rep 3rd Soviet Norwegian Symp, 26-28 May, 1986, PINRO, Murmansk

> Wassmann P, Reigstad M, Haug T, Rudels B and others (2006) Food webs and carbon flux in the Barents Sea. Prog Oceanogr 71:232-287

Zhukova NG, Nesterova VN, Prokopchuk IP, Rudneva GB (2009) Winter distribution of euphausiids (Euphausiacea) in the Barents Sea (2000-2005). Deep-Sea Res II 56:1959-1967

Submitted: February 8, 2010; Accepted: May 26, 2010

Proofs received from author(s): July 21, 2010 